\title{
WILLIAM KAELIN JR., SIR PETER RATCLIFFE ÉS GREGG SEMENZA NOBEL-DÍJAT KAPOTT A HIPOXIA JELPÁLYA FELFEDEZÉSÉÉRT (FIZIOLÓGIAI ÉS ORVOSTUDOMÁNYI NOBEL-DÍJ, 2019)
}

\section{WILLIAM KAELIN JR, SIR PETER RATCLIFFE, AND GREGG SEMENZA RECEIVED NOBEL PRIZE FOR THE DISCOVERY OF THE HYPOXIA SIGNALING (NOBEL PRIZE IN PHYSIOLOGY OR MEDICINE, 2019)}

\author{
Mandl József \\ professor emeritus, Semmelweis Egyetem Általános Orvostudományi Kar \\ Orvosi vegytani, Biokémiai és Molekuláris Biológiai Intézet \\ mandl.jozsef@med.semmelweis-univ.hu
}

\section{ÖSSZEFOGLALÁS}

\begin{abstract}
Az oxigén alapvető biológiai szerepe és az oxigén hiányához való alkalmazkodás fiziológiai és patológiai jelentősége és ténye közismert. Ennek ellenére, az oxigénérzékeléshez és az oxigénszint változásaihoz kötődő molekuláris mechanizmusok megismerése régóta váratott magára. A 2019-es Fiziológiai és orvostudományi Nobel-díjat az eukarioták világában alapvető élettani szabályozás molekuláris alapjainak megismeréséért végzett eddigi legátfogóbb kutatásokért ítélték oda két amerikai, William Kaelin Jr., Gregg Semenza és egy brit, Sir Peter Ratcliffe orvosnak. Az írás az oxigénérzékelés molekuláris alapjait és a felfedezéséért kitüntetett három kutató közreműködését foglalja össze.
\end{abstract}

\section{ABSTRACT}

Despite the fact that the fundamental biological role of oxygen and the physiological and pathological significance of the adaptation to hypoxia were well known the molecular mechanisms were lacking. The 2019 Nobel Prize in Physiology or Medicine was awarded to three physicians, two American scientists, William Kaelin Jr, Gregg Semenza and one British, Sir Peter Ratcliffe for their work on the molecular mechanisms of the most comprehensive physiological regulation in the world of eukaryotic cells. The molecular mechanisms of oxygen sensing, adaptation to hypoxia, and the contributions of the winners are briefly summarized in this paper.

Kulcsszavak: Nobel-díj, biokémia, jelátvitel, hipoxi

Keywords: Nobel-award, biochemistry, signal transduction, hypoxia 
A biokémiában, a molekuláris biológiában mindenki különböző rejtélyeket, izgalmakat, intellektuális örömöket kereshet és találhat.

A 2019. évi Nobel-díjat olyan szabályozási rendszer felfedezéséért ítélték oda, amelynek alapvető élettani és patológiai jelentősége nehezen vitatható. A meglepetés és a furcsaság ebben a díjban nem az, hogy miért ítélték oda, hanem inkább az, hogy ez a felfedezés miért ilyen későn jött.

Az orvostudományi Nobel-díjakat sokszor nem orvosok nyerik el. Ezúttal azonban három orvos, az amerikai William Kaelin Jr., a brit Sir Peter Ratcliffe és a szintén amerikai Gregg Semenza kapta a tudományos világ legnagyobb elismerését a molekuláris szintű szabályozások világában végzett kutatásaiért.

Minden biológiakönyv úgy kezdődik, hogy az élőlények, az azokat alkotó sejtek folyamatos kapcsolatban állnak a környezetükkel, „,anyagot cserélnek” vele. Az anyag-/energiacsere alapjelensége, hogy oxigén jelenlétében, aerob környezetben a (táp)anyagokból nyerhető energiamennyiség jóval több, az energiatranszformáció hatékonyabb, mint nélküle. Így az aerob élőlényeknek az oxigén életfeltétele, és a környezet oxigénellátottságának változásaihoz való folyamatos alkalmazkodás az egyik legjelentősebb követelmény. A Pasteur-effektust, a sejtekben zajló anyageserében oxigénfüggő szabályozások alapjelenségét a zseniális francia kutató már a 19. században, jóval a glikolízis (a legősibb energiatranszformáció) folyamatainak részletes megismerése elött felfedezte. Pasteur észlelte, hogy oxigén jelenlétében kevesebb „tápanyag” kell az anyagcseréhez, mint nélküle. Számos szabályozás közvetve vagy közvetlenül az oxigénnel függ össze a bioenergetikában, az intermedier anyagcserében és több más folyamatrendszerben. Az evolúció során ezért az oxigénellátottság a szervezet belső környezetének részévé vált. Az oxigénszállításhoz vörösvérsejtek, érrendszer szükséges. A sejtek az oxigénellátottság mértékének függvényében folyamatosan rendezik át, szabályozzák fehérjeszintézisüket, kisebb vagy nagyobb mennyiségben termelik azokat a fehérjéket, amelyek a változásokhoz történő sejt- és szervezetszintü alkalmazkodást szolgálják.

Az oxigén hiányának, a hipoxiának mint a kóros folyamatok egyik alapjelenségének megismerése sem sokáig váratott magára. Az oxigénellátottság csökkenése ismert betegségcsoportokkal van összefüggésben, többek között a vérszegénységgel (anémiák), a szívinfarktussal, az érpatológiával vagy számos idegrendszeri kórképpel. Szinte hihetetlen, hogy a hipoxiához történő sejt- és szervezetszintü alkalmazkodás molekuláris mechanizmusainak alapjai milyen sokáig maradtak ismeretlenek. Ezt a Nobel-díjat az eukarioták világában az eddigi legátfogóbb, alapvető élettani szabályozás molekuláris alapjainak megismeréséért végzett kutatásokért ítélték oda.

Számos molekuláris szabályozás fehérjék közötti, illetve fehérje-DNS-kötödések változtatásán alapul. Ezeket a kapcsolatokat gyakran egy kis molekula jelenléte közvetve vagy közvetlenül befolyásolja. Az oxigén ezen kis molekulák 
egyike. A HIF- (hypoxia inducible factor) fehérje az oxigéntől függő génkifejeződés meghatározó szabályozója, ez közvetíti a „van elég/nincs elég” információt a sejt fehérjeszintézisét irányító rendszeréhez. Többféle HIF van; a HIF-1 a legfontosabb a különböző HIF-izoformák közül. Fontos speciális fehérjék termelődnek az oxigénellátottságtól függően a szervezet különböző sejtjeiben. Vannak olyan specializált vesesejtek, amelyek például erythropoetint (EPO) képeznek. Az EPO a vörösvérsejtképzés kulcsfehérjéje. Más sejtek VEGF- (vascular endothelial growth factor) termelök, ez az érképződés legfontosabb növekedési faktora. Mind a vörösvérsejtek, mind az erek képződése a szervezetszintű oxigénfüggő szabályozások része. A HIF felfedezéséhez elsősorban az EPO-szintézis, illetve az érképződés tanulmányozásán keresztül vezetett az út.

A különböző, oxigénellátottságtól függő, ennek mértékében képződő fehérjék szintézisének szabályozásában közös, hogy a HIF-1 kötődik az azokat kódoló DNS megfelelő szakaszaihoz, de ehhez be kell jutnia a fehérjét termelő sejt citoplazmájából a magjába. A HIF-1-nek két alegysége van: $\alpha$ és $\beta$. A HIF-1 $\beta$ bent van a magban, viszont a HIF-1 $\alpha$ a citoplazmában található. Ez a két alegység képezhet olyan dimert a sejtmagban, amely a DNS adott szakaszához kötődik. A HIF-1 $\alpha$ sorsa kétféle lehet. Oxigén jelenlétében a HIF-1 $\alpha$ megváltozik; meghatározott aminosavai - többek között a prolinok - oxigénnel módosulnak, hidroxilálódnak a citoplazmában. Ennek következtében a HIF-1 $\alpha$ a hidroxilált prolinjain keresztül von Hippel-Lindau-fehérjét (VHL) köt. A képződött HIF-1 $\alpha$-VHLkomplex módosul, ubikvitinálódik, majd emiatt lebomlik. (A fehérjét módosító ubikvitinációs folyamatok egyik felfedezője a karcagi származású izraeli Avram Hersko, akinek az ezért kapott Nobel-díjáról a Magyar Tudomány már többször írt.) Ha azonban az oxigén mennyisége nem elég a HIF-1 $\alpha$ prolinjainak hidroxilációjához, akkor a HIF-1 $\alpha$ nem bomlik le, hanem a citoplazmából a magba jut, és ott a HIF-1 $\beta$-val társulva kötődik a DNS megfelelő szakaszaihoz. Ezzel indul az oxigénfüggő fehérjeszintézis, többek között az EPO vagy a VEGF-fehérjék termelése is. Ez az oxigénfüggő szabályozás müködésének lényege; de az élettani és kórélettani szerepeinek és a reguláció számos más mechanizmusának felfedezése ma is tart. Jelenleg elsősorban a daganatképzésben vizsgálják a HIF-rendszer különbözö funkcióit. A történet folytatódik...

E szabályozás eddigi számos ága-bogának megismerése több munkacsoportban dolgozó számos kutató munkájának eredménye. Ezek közül emelte ki a Nobel Bizottság a három idei nyertest. Az EPO-gén kifejeződését tanulmányozta az amerikai Gregg Semenza és a brit Peter Ratcliffe: ők fedezték fel e gén oxigénfüggő kifejeződésének mechanizmusát. 1995-ben Semenza írta le a HIF-1-t. A von Hippel-Lindau-kór öröklődő érdaganat. Az amerikai William Kaelin rákkutató mutatta ki, hogy ezt a betegséget a VHL-gén mutációja okozza. A daganatos sejtekben nincs VHL, nincs HIF-1 $\alpha$-lebontás, ezért oxigén jelenlétében sem csökken az oxigénfüggő génkifejeződés, és akkor is lesznek új erek, ha erre 
semmi szükség nincsen. Kialakul az érdaganat. Ratcliffe mutatta ki a HIF-1 $\alpha$ VHL-komplex képződését és ennek alapvető szerepét a szabályozásban. A HIF$1 \alpha$ prolin hidroxilációt Kaelin és Ratcliffe munkacsoportjai fedezték fel. Az ezt a folyamatot katalizáló prolin hidroxilázok azonosításában Ratcliffe munkacsoportja játszott döntő szerepet.

A tudomány történetében is bonyolíthatja a rejtélyeket, ha több néven ismerhetik meg ugyanazt - az esetünkben fehérjét -, és ez az azonosság - miként a kriminalisztikában is - később derül csak ki. A HIF-1 $1 \beta$-t korábban a tudományos világ egy része „leánykori nevén” ARNT-nak ismerte meg. A dolgokat megérteni vágyók öszinte örömére az ARNT részben rövidítések rövidítése: Ah Receptor Nuclear Translocator. Az Ah receptor (AHR) név az aryl hydrocarbon (aromás szénhidrogén) receptor fedőneve. Az AHR többek között kis molekulasúlyú szénhidrogéneket is érzékel úgy, hogy azok hozzá kapcsolódnak. Csak akkor kötődik a DNS-hez (más szakaszaihoz, mint a HIF), ha a magban a már szénhidrogént tartalmazó AHR dimert képez az ARNT-tal. Az AHR-ARNT-dimer DNS-hez történő kötődése több drog-/gyógyszermetabolizmus (DM) enzim és transzporter képződését fokozza.

Az enzimológia „monogám” tudománynak indult; egy enzim egy (illetve kisszámú) szubsztrát. Az angolszász irodalomban DM-néven ismert méregtelenítő biotranszformációs enzim- (később transzporter-) rendszer lényege, hogy az abban részt vevő enzimeknek (és transzportereknek) nincs egyetlen, „igazi” szubsztrátja, hanem ugyanazok az enzimek igen sok különböző szerkezetü molekulát kötnek, alakítanak át. Éppen amiatt, hogy a DM-enzimek nem specifikusak, tudunk alkalmazkodni a környezetünkben állandóan megjelenő, ,vegykonyhájában titkon megteszi" típusú újabb és újabb molekulákhoz, mert azokat is képesek átalakítani, „méregteleníteni”. Ezt a következtetést már régen levonták, de csak az elmúlt évtizedekben ismerték fel, hogy ezeknek az enzimeknek és transzportereknek a termelését szabályozó DNS-hez kötődő fehérjék, jelentős része ,árva”. Olyan receptorfehérje, amely nem rendelkezik egyetlen vagy kisszámú, hasonló szerkezetủ, kis molekulasúlyú hozzá kapcsolódó ligandummal (mint például a szteroid hormonok), az ,igazival”, amely kötődve a fehérjéhez (például szteroid receptorok) megváltoztatja annak szerkezetét, és így többek között a más fehérjékhez vagy DNS-hez történő kötődési tulajdonságait. Az AHR esetében is csak később jöttek rá arra, hogy éppen attól igazi, mert nincs egyetlen ,igazi” liganduma. (Több ,árva” receptort ismerünk.) Kiderült továbbá, hogy az ARNT és a HIF-1 $\beta$ ugyanaz. Tehát az ARNT mind az AHR-rel, mind a HIF-1 $\alpha$-val tud dimert alkotni, sőt még más fehérjékkel is. A történet folytatódik...

Ami pedig ennek a Nobel-díjnak számomra személyes vonatkozását illeti: van olyan elképzelés - Gregg Semenza több cikke is szól róla -, hogy a HIF-hez, AHR-hez hasonló (meghatározott kémiai szerkezetet, aminosav-sorrendet tartalmazó) DNS-kötő fehérjék - transzkripciós faktorok - a környezeti változásokhoz 
való alkalmazkodás eszközei. Ezen változások egyike az oxigén mennyiségének ingadozása, de ilyen például szervezetünk számára a gyógyszerszedés is. Munkacsoportunk témája sokáig a DM volt. Ez először az AHR-hez vitt el minket, majd az ezredforduló elött az ARNT-vel kezdtünk el foglalkozni. A 2000-ben harmincévesen, tragikus körülmények között Kaliforniában autóbalesetben meghalt nagyon tehetséges, kiváló munkatársam, Braun László azért volt a UCLA-n Oliver Hankinsonnál, mert ő ARNT- és Ah-receptor mutánsokkal dolgozott. Mutáns sejtvonalaival Budapesten is kísérletezhettünk. Többek között leírtuk, hogy a hipoxia-jelpálya szerepet játszik a VEGF-képződés fokozásában a diabétesz kitörésekor különböző szerveken, spontán diabetes állatmodellben; az AHR szerepét mutattuk ki az antioxidáns C-vitamin szintézise utolsó enzimjének szabályozásában; és gyógyszerkutatási célból xenograftokat készítettünk Hankinson különbözö hepatóma mutánsaiból daganatképződés tanulmányozására. A különböző jellegủ környezeti hatások befolyásolhatják a hipoxia jelpályát vagy az ahhoz hasonlókat hipotézisből indulva jutottunk el az UVB-sugárzáshoz és a bör keratinocita sejtjeihez. Peter Ratcliffe-et - a három Nobel-díjas közül az európait - részben ezért is hívtam meg elöadónak a 2005-ben Budapesten rendezett FEBS- (Federation of European Biochemical Societies) kongresszuson arra a szimpóziumra, amelyet én szerveztem. E-mail fordultával fogadta el a meghívást minden személyes ismeretség nélkül. Azt reméltem, hogy érdekelni fogja az addig nem vizsgált sugárzás mint dozírozható környezeti változás hatása a hipoxia jelpályára, az UVB-sugárzás HIF-1-re és a VEGF-szintézisre gyakorolt hatása keratinocitákon. Úgy éreztük, hogy szemléletileg is fontos új megfigyelésünk van. Effektusok voltak, cikkeket írtunk, valamennyire idéztek is minket, de szegény Laci elment, a Hankinson-kapcsolat idővel megszakadt, és az ezen a területen közölt munkáink ,,igazi” visszhangok nélkül maradtak. 2005-ben a leendő Nobel-dijas besorolta az UVB-HIF-VEGF-hatásunkat az interesting kategóriába; nem keltettük fel az érdeklődését.

Peter Ratcliffe-fel való kooperációnk abban volt sikeres, hogy a Margit híd budai hídföjétől rohanva még elértünk egy Batthyány tértől induló hajót. Esti dunai hajókázással egybekötve szervezték meg a FEBS-kongresszus gálavacsoráját. Ratcliffe a Rákóczi úti Metropol Szállodában lakott, és kérte, hogy menjünk együtt. A Blahán, a villamosmegállóban találkoztunk. Késett. A hatossal mentünk át a Margit hídon, aztán pedig futottunk. Ma már tudom, hogy a metró jobb választás lett volna. ,We made it”, kiáltott fel boldogan mosolyogva, amikor izzadtan, lihegve a hajóállomás stégjére léptünk közvetlenül a hajó indulása elött. Azt, hogy a Nobel-díj hallatán mit mondott, nem tudom, de az is lehet, hogy ugyanezt.

He made it - megérdemelte. 